\title{
Evaluation of Rare Study Program Interest in UIN Ar Raniry Banda Aceh
}

\author{
Suprapto $^{1}$, Achmad Habibullah ${ }^{2}$, Lisa'diyah Mf. ${ }^{3}$, Nunu Ahmad An Nahidl ${ }^{4}$ \\ \{supraptolitbang@gmail.com¹, achmadhabi@gmail.com² dan lisa.litbang@gmail ${ }^{3}$ dan \\ intersym2013@gmail.com ${ }^{4}$ \} \\ Peneliti Puslitbang Pendidikan Agama dan Keagamaan ${ }^{1,2,3,4}$
}

\begin{abstract}
After the transition of the status of IAIN to UIN, it affects the community's lack of interest in choosing religious study programs compared to general religious study programs. This study uses a qualitative method, through documentation study techniques by collecting and analyzing official documents, documents whose validity is related to rare study programs interested in in-depth interview techniques. This research resulted in: 1) rare religion study program enthusiasts at Ar Raniry State Islamic University are Islamic Community Development Study Program, Islamic Aqeedah Study Program, and Philosophy, School of Comparative Study Program. 2) Alumni of rare study programs interested in working as employees in the Ministry of Religion, religious counselors, board members, regional government, TNI and Polri, entrepreneurship, journalists, writers, and religious teachers. Recommended: 1) The Ministry of Religion must maintain a rare religious study program of interesting ones. 2) Needs strategic and technical steps in the Aqeedah and Islamic Philosophy (AFI) study program, through: Rector and Dean's Policy of graduating students who are not accepted to other study programs with graduated standard grades to enter the rare study program applicants; open a special line "Scien achievement, art and sports"; Empower lecturers, community leaders and alumni to socialize religious study programs to MA students; Vocational High School and Islamic boarding school; MOU between UIN Ar Raniry and local government in rare study program enthusiasts; and Giving scholarships to students in quiet study programs.
\end{abstract}

Keyword: Evaluation, Rare Study Program Interest.

\section{Introduction}

\subsection{Background}

The change in the form of IAIN) to UIN was due to the low interest of prospective new students who chose to continue their studies at IAIN, in addition to philosophical reasons to eliminate the scientific dichotomy between Islamic sciences and general sciences. Along with these changes, debates arose, among others related to concerns about the exclusion of religious studies programs and being unable to compete with study programs that study general scientific fields. If this happens, it will dwarf religious scholarship which was initially the main task before the change in the shape of the institution.

In the context of Islamic religious tertiary institutions, the Directorate of Islamic Higher Education in the Indonesian Ministry of Religion in 2015 [1] stated "the variants consist of: Universities, Institutes and Colleges. A total of 700 universities, with 643 tertiary institutions having private status, and 57 state-owned institutions, spread from Aceh to Papua. Of these, 17 of them status as State Islamic University (UIN). Whereas if seen from the number of study programs, the comparison of Religion study programs and general study programs: Total study programs (954), with the number of religious study programs as much as $722(75.68 \%)$, while the number of general study programs was $232(24.32 \%)$. At PTKI UIN there are $163(53.8 \%)$ 
religious study programs, and $138(45.54 \%)$ general study programs. At IAIN, there are 300 $(82.64 \%)$ religious study programs, and $57(15.7 \%)$ general study programs. In STAIN, there are $259(86.62 \%)$ religious study programs, and $37(12.37 \%)$ general study programs [2]. Among the existing religious studies programs can still be grouped into two study program variants, namely religious study programs with multidisciplinary scholarship and religious study programs with pure scholarship. (p. 308-309). [3] states that public interest for studies at UIN in the last 3 (three) years (at the time of the study) increased by 164\%, interest in "Religious Study Program" (Adab, Da'wah, Syari'ah, Ushuluddin, and Tarbiyah) also increased up to $154 \%$, even the quality of the "General Study Program" (Science, Technology, and Social Sciences, Humanities) also increased on the right track and enthusiasts increased by $176 \%$. To obtain information and related data, related to the existence of pure religious study programs in PTKI, it is important to conduct this research.

The problem is, in the context of interest, several studies state that after the transition of IAIN status to UIN, people's interest in entering UIN is higher in general study programs such as IT, medicine, economics, and law, while for religious studies programs that have links to the world of work (study programs) Multidisciplinary Islam) is also still relatively high in demand, but for religious study programs with pure scholarship there is very little demand. This is evidenced by the provision of affirmations including through scholarships and other ways to attract prospective students.

\subsection{Research objectives and purpose}

This study aims to determine the existence of Religion study programs with pure scholarship at UIN throughout Indonesia; Public interest / middle level students / students towards the Religion study program at PTKI; Distribution and progress of alumni of Religion study program with pure knowledge in the world of work; The policy of universities to maintain the existence of pure scientific study programs at UIN.

This research is useful for policy-making in maintaining and developing religious study programs with pure science at UIN throughout Indonesia, both conducted by each university and by the ministry of religion, in this case, the directorate of Islamic religious higher education.

\subsection{Research methods}

The research method used in this study is a qualitative method, though: first, the documentation study technique by collecting and analyzing official documents, documents whose validity is related to the rare study program enthusiasts. Second, in-depth interview techniques using a semi-structured interview type, in which the researcher seeks the opinions and ideas of sources more openly so that the problem becomes clear. Researchers need to listen carefully and record or record what was stated by the source.

\section{Theoretical study}

\subsection{Existence of religion study program}

Along with the community's response in responding to the development of science and technology, and also to eliminate the dichotomous thinking that has occurred so far, between Islamic sciences and general science, a change of institutional form from the State Islamic Institute (IAIN) and the scientific field is proposed. Islamic religion becomes the State Islamic 
University (UIN) so that it can open general study programs. The initial changes began with UIN Syarif Hidayatullah Jakarta, UIN Sunan Kalijaga Yogyakarta, UIN Malik Ibrahim Malang, and UIN Syarif Qasim Riau. Subsequently followed by other IAINs who asked for a change in the shape of the institution, so that currently developing into 17 UIN throughout Indonesia.

The change of IAIN to UIN was followed by the development of certain metaphors and symbols. It is intended to show the status and position of general knowledge on one side and Islamic science on the other side. Center for Research and Development (2013) at Syarif Kasim Riau UIN is known as the concept of "Building an Islamic Paradigm Science". At UIN Syahid the concept of "Integration of Sciences" is known. At UIN Sunan Gunung Djati Bandung, the concept of "Wahyu Guiding Science" is known. At UIN Sunan Kalijaga Yogyakarta, the concept of "Integration-Interconnection" is known. At UIN Malang, the concept of "Tree of Science" is known. At Alinuddin Makassar State Islamic University, the concept of "Cypress Tree" is known.

With the change in the shape of the institution, according to Nur Syam, there are three types of study programs managed by the State Islamic University, namely: pure Islamic science study program, multidisciplinary Islamic study program, and general science study program. Based on the mapping results, Nur Syam further stated on http://nursyam.uinsby.ac.id/ that in the case of UIN Sunan Ampel Surabaya the proportion of pure Islamic study programs was 30\%, multidisciplinary religious study programs $44 \%$ and general study programs $26 \%$. (P .832). At UIN and other PTKI, of course, they have different proportions, with different study program variances and names. This depends on the capacity of the teaching human resources and scientists, as well as on the demands and needs of the surrounding environment. In the context of the religious studies program at PTKI, there are currently 55 variants of study programs (religion) whose existence is different from the study programs (general or non-religious), both mentions or substance [5].

\subsection{Management concepts}

Management has a key role in the organization in managing, coordinating the activities of sub-systems and connecting them with the environment. In other words, management is a process in which existing resources are integrated into a system to achieve goals. Whereas managers will be responsible for integrating the elements of humans, machines, and money and others into being productive. The manager seeks to coordinate activities towards the achievement of organizational system goals.

There are two types of approaches that can be used to study management, first, showing administrative processes, which consist of; planning, organizing, and monitoring to achieve organizational goals. Second, study the organizational sub-systems, which include the tasks of strategy, coordination, and operations. Strategy, connecting organizations with the environment, and designing a comprehensive system and plan. Coordination: integrating activities within the organization. Operations: implement the achievement of objectives effectively and efficiently.

In carrying out these tasks, environmental systems, time perspectives, opinions, general processes, and decision-making techniques are needed. Management in organizations is the coordination of group efforts to achieve predetermined goals. On [6] coordination was mainly influenced by: (1) through people, (2 ) through techniques, (3) in an organization, and (4) toward goals. Management is the process of integrating human and material resources into an overall system to achieve goals. 


\subsection{Educational management objectives and benefits}

The objectives and benefits of education management according to [7] include the following:

a. The realization of learning and the active, innovative, creative, effective and fun learning process (PAIKEM).

b. The creation of active students

c. Fulfillment of one of the four competencies of educators and education (professional competence as educators and education personnel as managers).

d. The purpose of effective and efficient education.

e. Providing education staff with theories about the processes and tasks of educational administration (supported by the profession as an education management manager or consultant).

f. Offering him the problem of education quality. (p. 125).

\subsection{Educational management functions}

Education Management related to the special education process with the learning process. In this connection, there are several functions of education management, according to [8] as follows:

a. The planning function, organizing various activities to determine needs, determine the strategy to achieve goals, determine the contents of educational programs, etc.

b. Functions, including management of personnel, facilities and infrastructure, distribution of tasks and responsibilities in integral management.

c. The agreed coordination function stabilizes the various tasks, responsibilities and obligations for the implementation of the tasks and assistance of educational programs.

d. Motivation function (mobilization), which supports to improve process efficiency and support training programs.

e. The control function, which refuses to supervise, renewal, monitor, improve the weaknesses in the education management system. (pp. 81-82).

\subsection{CIPP evaluation model}

To find out the implementation of the program in this research target was carried out using the CIPP evaluation model. On [9] CIPP is a CIPP evaluation model. The CIPP evaluation model is an evaluation model that consists of four evaluation components, namely Context, Input, Process, and Product (CIPP). CIPP stands for context evaluation, which means the evaluation of context, input evaluation means the evaluation of input, process evaluation means the evaluation of the process, and product evaluation means the evaluation of results.

Context Evaluation is primarily to find out the strengths and weaknesses that evaluation has. Input Evaluation helps set decisions, determine available sources, what alternatives are taken, what are the plans and strategies for achieving goals, and what are the work procedures for achieving them. The input evaluation component includes: 1) Human resources, 2) Supporting facilities and equipment, 3) Funds or budget, and 4) Various procedures and rules needed. Process Evaluation is used to detect or predict procedure designs or implementation plans during the implementation phase, provide information for program decisions and as a record or archive of procedures that have taken place. Product Evaluation to help make further decisions, both regarding the results achieved and what is done after the program runs. 


\section{Results and discussion}

\subsection{Research results}

\subsubsection{Profile of UIN Ar Raniry Banda Aceh}

IAIN is an abbreviation of the State Islamic Institute of Religion and the word Ar-Raniry which was given to IAIN Banda Aceh is the name of a great Ulama and mufti who was very influential during the time of Sultan Iskandar Tsani (ruled 1637-1641). The great cleric was full name Sheikh Nuruddin Ar-Raniry who came from Ranir (now Rander) in Gujarat, India. He has made a very valuable contribution to the development of Islamic thought in Southeast Asia, especially in Aceh. Right on October 5, 2013, when it is 50 years old, the College will change its name from Instituut to University through PER PRES No. 64 of 2013 issued and entered into force on October 1, 2013, under the name Ar-Raniry State Islamic University (UIN Ar-Raniry).

Thus, starting on October 1, 2013, the name of IAIN Ar-Raniry began to be erased legally, and eventually, it will also be erased little by little from the hearts of the people of Aceh in particular, and the people of Indonesia, and other communities in the world in general.

In its development, UIN Ar Raniry continues to improve itself by opening some Study Programs that suit the needs of the community. Not only that to improve its existence, but this institution has also opened a master's program (S2) in 1089 and a doctoral program (S3) in 2002. With the strata 1 to 3 strata study programs this institution is expected to give birth to educators, preachers, thinkers, and scholars who are professional and by developments and changing times.

A vision of UIN Ar-Raniry "To be a University that excels in development and integration, Islamic science, science, technology, and art". While the mission is 1) Give birth to graduates who have academic, professional and/or vocational skills that are competitive, future-oriented and of noble character; 2). Developing a multidisciplinary and integrative research tradition based on Islamic Sharia; 3). Implementing knowledge to build civil society, which has faith, knowledge, and charity [10].

\subsubsection{Student situation}

The number of students of UIN Ar Raniry in the Academic Year 2017/2018 is 5,708 students, as detailed: Sharia Faculty as many as 801 people; Faculty of Tarbiyah and Teacher Training 1,844 people; Ushuludin Faculty as many as 315 people, Faculty of Da'wah and Communication as many as 452 people, Faculty of Adab and Humanities as many as 374 people; Psychology Faculty as many as 210 people; Faculty of Social Sciences and Government as many as 309 people; 748 Faculty of Economics and Business Islam; and Postgraduate Masters (167 people), Masters (51 people) [10].

\subsubsection{Lecturer circumstances}

In the Profile of Ar Raniry Banda Aceh UIN (2017) the lecturers of Ar Raniry Banda Aceh UIN total 418 people consisting of 408 people from faculties and 10 lecturers of DPK. In detail, the number of lecturers at the Faculty of Sharia and Law can be conveyed by 52 people $(\mathrm{S} 1=$ 4, S2 = 31, S3 = 27); Tarbiyah and Teacher Training Faculty totaled 151 people $(\mathrm{S} 1=8, \mathrm{~S} 2=$ $113, \mathrm{~S} 3=30)$; Ushuludin Faculty totaling 42 people $(\mathrm{S} 1=6, \mathrm{~S} 2=28, \mathrm{~S} 3=8)$; Faculty of Da'wah and Communication totaling 54 people $(\mathrm{S} 1=2, \mathrm{~S} 2=47, \mathrm{~S} 3=5)$; Faculty of Adab totaling 45 people $(\mathrm{S} 2=37, \mathrm{~S} 3=8)$; The Faculty of Psychology is 7 people $(\mathrm{S} 1=3, \mathrm{~S} 2=4)$; Faculty of 
Social Sciences and Government numbered 3 people ( $2=3$ ); The Faculty of Economics and Business Islam totals 21 people $(\mathrm{S} 1=1, \mathrm{~S} 2=15, \mathrm{~S} 3=5)$; The Faculty of Science and Technology totaled 33 people $(\mathrm{S} 2=30, \mathrm{~S} 3=3)$ and DPK Lecturers amounted to 10 people (S1 $=1, \mathrm{~S} 2=8, \mathrm{~S} 3=1)[10]$.

\subsubsection{The state of administrative personnel}

In the Profile of Ar Raniry Banda Aceh UIN (2017) The total administrative staff of Ar Raniry Banda Aceh UIN total 215 people consisting of Academic and Student Administration Bureau (16 people); General Administration Bureau (25 people; Faculty of Sharia and Law (30 people); Tarbiyah and Teacher Training (42 people); Ushuludin and Philosophy Faculty (14 people); Da'wah and Communication Faculty (15 people); Adab and Humanities Faculty (17 people) ; Faculty of Psychology (5 people); Faculty of Social and Government Sciences (4 people); Islamic Economics and Business Faculty (3 people); Saint and Technology Faculty (4 people); Postgraduate Program (11 people); Research Institute (4 people) ); Community Service Institutions (4 people) Language Centers (3 people); Information and Computer Centers (5 people); Library ( 8 people); Quality Assurance Institutions (3 people); PSGA (2 people) and SPI (2 people) [10].

\subsubsection{State of facilities and infrastructure}

The facilities and infrastructure available to support education at Ar Raniry State Islamic University of Banda Aceh consist of a Mosque; Mushala; Library; Student Activity Center Laboratory Laboratory; Sports Venue (soccer field, basketball court, and rock climbing); Polyclinic; Museum [10].

\subsubsection{Study program aqeedah and Islamic philosophy}

The Aqeedah Study Program and Islamic Philosophy of UIN Ar Raniry Banda Aceh is a superior study program owned by the Faculty of Ushuludin and the Philosophy of UIN Ar Raniry. Aqeedah Study Program and Islamic Philosophy is a new manifestation of the Department of Aqeedah Philosophy which has been established since 1974. In its work, this study program has given birth to hundreds of scholars who now work in various sectors of work for both the public and private sectors. Constitutionally the Aqeedah Study Program and Islamic Philosophy are present to introduce the Islamic scientific treasures comprehensively including the study of kalam (theology), philosophy, Sufism, and Islamic thought both classical and contemporary.

The competency of the Aqeedah Study Program and Islamic Philosophy is projected to produce graduates who have academic, futuristic, competitive abilities with Islamic aqidah foundation and have good character. Has a broad Islamic insight as a young Muslim scholar who is able to answer the religious problems that arise in society. Have the expertise/skills to conduct scientific research as a young, reliable researcher.

Total the Vision of Islamic Aqeedah Study Program and Philosophy is "Becoming the leading Study Program in the study of Islamic Aqeedah and Philosophy with an integrative and interdisciplinary approach in Indonesia in 2025". While the mission: 1). Give birth to scholars who have academic, futuristic, competitive and noble abilities; 2) Developing the study of Aqeedah and Islamic Philosophy based on scientific research through an integrative and interdisciplinary approach; 3) Implement and publish the results of Aqeedah and Islamic 
Philosophy research in the context of enriching knowledge and realizing inclusive civil society; 4) Establishing Prodi partnerships with various productive and innovative parties in realizing higher education tri dharma.

Aqidah Study Program and Islamic Philosophy in 2018/2019 academic year totaling 246 people consisted of. In detail the number of quota, registrants, accepted and the number of students last three years as follows:Total quota of students in the last three years: $2016 / 2017=$ 80 people, $2017 / 2018=80$ people, $2018 / 2019=80$ people. Number of registrants in the last three years: $2016 / 2017=67$ people $2017 / 2018=92$ people, $2018 / 2019=59$ people. Number of students accepted: $2016 / 2017=32$ people, $2017 / 2018=61$ people, $2018 / 2019=48$ people. Number of students in the last three years: $2016 / 2017=155$ people, $2017 / 2018=213$ people, $2018 / 2019=246$ people.

The total number of lecturers of the Aqidah Study Program and Islamic Philosophy totaled 14 (fourteen) people consisting of one professor, ten doctors, and three doctoral candidates. While the administrative staff numbered one person.

The curriculum of the Aqidah Study Program and Islamic Philosophy UIN Ar Raniry Banda Aceh refers to the vision, mission, and objectives of the AFI study program based on KKNI. The distribution of the courses of Aqeedah and Islamic Philosophy courses mentioned above, the core courses in this study program are Islamic Sharia Studies; Islamic legal philosophy; Classical Islamic Philosophy; Modern Islamic Philosophy; Islamic epistemology 1 and 2; Philosophy research methodology; Modern Kalam Science; Classical Kalam Science; Orientalism and Occidentalism; Nusantara Islamic Thought; Value Philosophy; Human Philosophy *); Cultural Philosophy *); Divine Philosophy *); Political Philosophy; Hermenitics of Islam; Metaphysical Ontology; Islam and Modernity; Introduction to Tasauf; Sufism Akhlaki; Sufism of the Fakafi; Tasauf Science Text Study *); Text Study of Islamic Philosophy *); Sufism and; Psychotherapy and Psychology of Religion. *) Optional.

Aqidah Study Program and Islamic Philosophy are connected to all the facilities at UIN Ar Raniry's campus, such as the Library, Foreign Language Development Center, Mahad Ali, Student Activity Center, Sports Activity Center, Health Service Center and Student Dormitory. Besides that, other facilities are available such as offices, lecture halls, mosques, internet networks, toilets, and others [10].

\subsubsection{Religion study program in the last 3 years}

Ar Raniry IAIN Banda Aceh became Ar Raniry State Islamic University following Perpres No. 64 of 2013 dated October 1, 2013. Along with these changes, the number of students experienced a good change in the faculties of the study program. The following is the number of prospective students who are interested in the last three years.

Based on data on the number of interested students in the various religious studies programs mentioned above over the past three years, the following rare religious study programs can be submitted. 
Table 1. Lowest interest in study program UIN Ar Raniry Banda Aceh

\begin{tabular}{|c|c|c|c|c|c|c|c|}
\hline \multirow[t]{2}{*}{ No } & \multirow[t]{2}{*}{ Program study } & \multicolumn{2}{|c|}{2015} & \multicolumn{2}{|c|}{2016} & \multicolumn{2}{|c|}{2017} \\
\hline & & Total & $\begin{array}{l}\text { Rang } \\
\text { king }\end{array}$ & Total & $\begin{array}{l}\text { Rangk } \\
\text { ing }\end{array}$ & Total & $\begin{array}{l}\text { Rang } \\
\text { king }\end{array}$ \\
\hline 1 & $\begin{array}{lr}\text { Filsafat Agama } & \text { dan Ilmu } \\
\text { Aqidah } & \text { Fakultas } \\
\text { Ushuluddin } & \end{array}$ & 4 & 1 & 49 & 4 & 19 & 1 \\
\hline 2 & $\begin{array}{l}\text { Pengembangan Masyarakat } \\
\text { Islam Fakultas Dakwah dan } \\
\text { Komunikasi }\end{array}$ & 6 & 2 & 31 & 3 & 39 & 3 \\
\hline 3 & $\begin{array}{l}\text { Ilmu Perbandingan Agama } \\
\text { Fakultas Ushuluddin dan } \\
\text { Filsafat }\end{array}$ & 10 & 3 & 17 & 1 & 22 & 2 \\
\hline 4 & $\begin{array}{l}\text { Sosiologi Agama Fakultas } \\
\text { Ushuluddin dan Filsafat }\end{array}$ & 14 & 4 & 18 & 2 & 92 & 4 \\
\hline
\end{tabular}

\subsection{C.I.P.P on Islamic aqidah and philosophy products}

\subsubsection{Context}

The presence of the Aqidah Study Program and Islamic Philosophy determines the birth of Ar Raniry IAIN Aceh Aceh. Aqeedah Study Program and Islamic Philosophy were established based on the Decree of the Director-General of Islamic Community Guidance Number: KPP / D.VI / 718/74, December 23, 1974, About Departments at Faculties in the State Islamic Institute (IAIN). Subsequently, on January 28, 2014, the Director-General of Islamic Education's Apostasy Letter No. 442 of 2014 was issued concerning the Extension of the Implementation License and the Adjustment of Study Program Nomenclature in the Ar Raniry Darussalam Banda Aceh State Islamic University Bachelor Program from the Aqidah Study Program and Philosophy into the Aqidah Study Program. In its development, a Decree of the DirectorGeneral of Islamic Education Number 6943 of 2016 concerning Amendment and Adjustment of Nomenclature of Islamic Religious Studies Program (PTKI) from Aqidah Science Study Program became Aqidah Study Program and Islamic Philosophy.

\subsubsection{Input}

The input of the Aqidah and Philosophy study program students came from Madrasah Aliyah graduates as much as $27.02 \%$; SMA as much as $51.35 \%$ and SMK as much as $8.10 \%$ and Boarding Schools as much as $13.51 \%$.

The number of lecturers in the Study Program Aqidah and Islamic Philosophy totaled 14 people consisting of one professor / Professor namely Prof. Dr. Syamsul Rijal; The Ten Doctors are Dr. T. Safir Iskandar Wijaya, MA; Dr. Damanhuri Basyir, MAg; Dr. Lukman Hakim M.Ag.; Dr. Husna Amin, M.Ag.; Dr. Juwaini Saleh, M.Ag.; Dr. Fuad Ramly, S.Ag. M.Hum, Dra Suraiya I.T.MA. Ph.D.; Dr. Ernita Dewi, Sag. M. Hum; DR. Nurkhalis, Sag. SE, M.Ag. Dr. Faizal Muhammad Nur, LC., MA .; and Three doctoral candidates, namely: Syarifuddin, S.Ag. M.Hum.; Zuherni Abdullah, M.Ag. and Happy Saputra, M.Fil.I.

While the Administration Staff is 1 person (Arif Gunandar, S.Ud). The organizational structure of the Aqidah Study Program and Islamic Philosophy consists of the Dean: Drs. Fuady, 
M.Hum. Deputy Dean 1: Dr. Abdul Wahid, M.Ag .; Deputy Dean 2: Muhammad Zaini, M.Ag .; Vice Dean 3: Syarifuddin, S.Ag, M.Hum .; Head of Study Program: Happy Saputra, S.Ag. M.Phil.I. Secretary of Study Program: Syarifuddin, S.Ag, M.Hum.

\subsubsection{Process}

Lecture System of Aqeedah Study Program and Islamic Philosophy through IntraCurricular, Co-Curricular and Extracurricular activities. Intrakurikuler activities are activities that are carried out by the Aqeedah Study Program and Islamic Philosophy which are already regular, clear. and systematically scheduled which is the main course of study in the process of educating students. Kokurikuler activities are activities that support and help extracurricular activities usually carried out outside the extracurricular schedule with the intention that students better understand and deepen the material in extracurricular, usually, these activities take the form of assignments or homework or other actions related to extracurricular material that must be completed by students. While Extracurricular activities are activities that are carried out outside lecture hours (outside extracurricular), and most of the material is also outside extracurricular material, whose main function is to channel/develop students' abilities according to their interests and talents, expand knowledge, learn socialization, add skills, fill time free, and so on.

The lecture strategy is implemented using a variety of strategies and techniques that encourage students to think critically explore, create and experiment using various learning resources. In the Aqidah Study Program and Islamic Philosophy the learning process is generally carried out in the classroom.

The lecture method developed by Aqidah Study Program lecturers and Islamic Philosophy through 1) Face-to-face method in the classroom, this method is carried out in every lecture, it is intended to provide supporting theories for students so that they can understand, know, things related with the courses given. 2) Discussion method, this method is used in certain times with certain topics, this method is intended to increase students' understanding of the theories given and problems faced by the topics discussed. 3) Independent and group assignments, the assignment of independent and group assignments are given to students as a training tool to solve various problems independently as well as teamwork, the results of which can be a feedback for lecturers. 4) Field Experience Practices (PPL), PPL is applied in the form of teaching practices and other educational activities in school institutions. PPL conducted by students in one place for students to get reliable professional experience. In PPL students will be confronted with the real conditions of application in scientific fields, such as the ability to teach, the ability to socialize and negotiate, as well as other educational managerial abilities. Each lecturer in the lecture is required to make a Syllabus and SAP (Lecture Program Unit). While extra-curricular activities are generally managed by students with the guidance of lecturers in the form of teaching, halaqah, takhlim/ takhsin, studying in Mahad about Arabic, English, personality, and entrepreneurship.

Community service at Aqidah Study Program and Islamic Philosophy is done through KPM (Community Service Lecture); Social Service; Safari Ramadan; Social activities by events in the community such as: helping natural disasters carried out by Lecturers and Students.

In the research activities lecturers are assisted by students. Students in this case are positioned as research assistants while Lecturers as research leaders. Research for lecturers is funded through the Research Institute (once a year per lecturer who passes the selection) through individual research, collaboration and study program studies. While from other institutions depending on each lecturer 
As for the completion of the final project, students must register at the study program after completing all the requirements followed by thesis munaqasyah trial. Study Program schedules the trial schedule and the examination board setting in consultation with Deputy Dean 1; holding the trial until completion.

The stages of completing the final project students must take a comprehensive examination and thesis based on the Comprehensive Examination SOP and Thesis Munaqasyah SOP.

\subsubsection{Product}

Based on the results of an interview with Happy Saputra [10], the number of alumni of the Aqidah Study Program and Islamic Philosophy as of 2008 totaling 168 people. They work as employees in the Ministry of Religion, TNI and Polri (Polda investigators), Religious Instructors, Board Members, Regional Government, Interpreneurship, Journalists, Writers and becoming Ustadz. For alumni users on the performance and integrity of the alumni of Islamic Aqidah and Philosophy, they are generally very positive, they can work well, loyal and can work together in teams even though they do not have special skills but generally they are easy to adapt in their work environment.

Aqidah Study Program and Islamic Philosophy do not yet have a Journal, until now it still joins journals in the Faculty of Ushuludin, namely: Subtantia Journal and Muasiroh Journal. The number of articles in a journal is at least 9 (nine) articles. Lecturers are required to make 2 (two) articles each year. As for alumni, at least 1 article is sourced from a thesis.

Awards that have been obtained by Aqidah Study Program and Islamic Philosophy until now have not been there but for the awards of lecturers and students already exist in the form of competition awards and other activities, such as: best lecturers, favorite lecturers, model lecturers, art competitions and sports for students, such as speech competitions, calligraphy competitions, and sports.

Alumni of Aqidah Study Program and Islamic Philosophy who become Community, Politics and Bureaucrats Figures include: Prof. Dr. Ahmad Daudi as the Acehnese community leaders; Prof. Dr. Syamsul Rijal, M.Ag., as a lecturer in the Greater Aceh mosque; Dr. Damanhuri, M.Ag, as a public figure, writer and speaker; Dr. Lukman Hakim, M.Ag. as a public figure, researcher and writer and Dr. Faisal Muhamad Noor, LC, M.A. as a figure of Sufism.

\subsection{Discussion}

The existence of Islamic Religious Colleges (PTKI) is increasingly becoming a choice for prospective students who wish to continue their education to tertiary level. Along with the change of IAIN into UIN, it encourages people to enter UIN higher, especially in general study programs such as the faculties of law, economics, psychology, medicine, etc. while for purely religious study programs such as Religion / Comparative Religion study programs, Comparative Schools, Aqeedah and Islamic Philosophy, Science Developing Islamic societies is very less in demand, one of the reasons is because of unclear employment opportunities after they finish their studies. This is different from religious study programs that have links to the world of work that are still in great demand, such as the Department of Islamic Education (PAI), the department of sharia economics / sharia banking. It has an increase every year.

The change of IAIN to UIN resulted in the marginalization of religious study programs that could not compete with study programs that studied general scientific fields. In other words, although UIN can attract many students, the majority of students choose general study programs and only a few choose religious study programs, let alone study programs that study the science 
of pure religion. If this happens, it will dwarf religious scholarship which was initially the main task before the change in the shape of the institution.

Based on the data on the number of interested students in various religious studies programs in Ar Raniry UIN, Banda Aceh, the study programs that experienced rare applicants were the Aqeedah Study Program and Islamic Philosophy of the Ushuludin Faculty and Philosophy in addition to the Study Programs of Religious Studies in the Faculty of Sharia and Law, and the Islamic Community Study Program in the Faculty of Da'wah and Communication.

Aqidah Study Program and Islamic Philosophy UIN Ar Raniry Banda Aceh was established based on the Decree of the Director General of Islamic Community Guidance Number: KPP/D.VI/718/74, December 23, 1974 About Departments at Faculties in the State Islamic Institute (IAIN). Subsequently, on January 28, 2014, the Director General of Islamic Education's Apostasy Letter No. 442 of 2014 was issued concerning the Extension of Execution License and Adjustment of Study Program Nomenclature in the Ar Raniry Darusalam Banda Aceh State Islamic University Bachelor Program from Aqidah Study Program and Philosophy into Aqidah Study Program. In its development, a Decree of the Director General of Islamic Education Number 6943 of 2016 concerning Amendment and Adjustment of Nomenclature of Islamic Religious Studies Program (PTKI) from Aqidah Science Study Program became Aqidah Study Program and Islamic Philosophy.

Although the Aqeedah Study Program and Islamic Philosophy are rare, enthusiasts need to be packaged in such a way that students, in addition to getting their knowledge, also get other skills that support when entering the workforce. He considered, the lack of interest in religious study programs at PTKIN because prospective students still have a mindset that tends to be pragmatic. "Religious study programs are considered irrelevant to the needs of the workforce today." And efforts need to be made so that religious study programs at PTKIN are again attractive to prospective students. One way is for universities to be more creative and innovative. Besides that, for rare study programs interested in needing to conduct socialization, better service becomes the main instrument of student attraction. PTKI as a business unit engaged in services, good service is a necessity. Provision of competent lecturers, proper allocation of hours, strengthening of religious disitingsi, quality assurance and others.

For rare study programs interested in, such as Aqeedah and Islamic Philosophy, the number of students is not important, what is important is that Aqidah study programs and Islamic Philosophy have qualities. But because of the demands of IKU, the study program is looking for alternatives to increase the number of students. Facing rare study program applicants, it is necessary to: 1) the existence of the rector's policy and the dean graduating students who are not accepted to other study programs with a standard of university graduation to enter the AFI study program; 2) religious department socialization among high school and vocational high school MA students and pesantren involving alumni, power lecturers and community leaders; 3) Student internships to government and non-government agencies that are relevant to AFI study programs; 4) MOU between AFI Study Program with government and private institutions; 5) friendship between stakeholders with components in the AFI study program

\section{Closing}

\subsection{Conclusions}

1. Rare religions study programs at UIN Ar-Raniry Banda Aceh are Study Programs in the Study of Religion of the Faculty of Sharia and Law, Study Program of Islamic Community Development Faculty of Da'wah and Communication, Study Program Aqeedah and 
Islamic Philosophy of the Faculty of Islamic Studies and Philosophy, Comparative Study Program of the Faculty of Sharia and Law Law and Diploma III Library Science Adab Humanities faculty.

2. Islamic Studies Program and Islamic Philosophy UIN Ar Raniry was born based on the Decree of the Director General of Islamic Community Guidance Number: KPP / D.VI / 718/74, December 23, 1974; Decree of the Director General of Islamic Education Number 442 of 2014 Date 28 January 2014 and Decree of the Director General of Islamic Education Number 6943 of 2016 dated 7 December 2016 Regarding Changes and Adjustment of Nomenclature of Islamic Religious Higher Education Study Program (PTKI) from Aqidah Science Study Program to Aqidah Study Program and Islamic philosophy.

3. The lecture strategy is implemented by using various strategies and techniques that encourage students to think critically to explore, create and experiment by utilizing the various learning resources available. The lecture methods developed are: 1) Face-to-face method in class, 2) Discussion method, 3) Independent and group assignments. and 4) Field Experience Practices (PPL).

4. Alumni of Aqidah Study Program and Islamic Philosophy work as employees in the Ministry of Religion, Religious Instructors, Members of the Council, Regional Governments, TNI and Polri, Interpreneurship, Journalists, Writers and becoming Ustadz. Among them there are those who become Community Leaders, Prominent Figures and Bureaucrats.

5. For rare study programs interested in, such as Aqeedah and Islamic Philosophy, the number of students is not important, what is important is that Aqidah study programs and Islamic Philosophy have qualities.

\subsection{Recommendations}

1. The Ministry of Religious Affair must continue to maintain a rare religious study program interested in PTKI.

2. Needs strategic and technical steps in the study program of Aqeedah and Islamic Philosophy (AFI), through:

a. Rector and Dean's policy to graduate students who have not been accepted at other study programs with a standard grade of graduation to enter the rare study program applicants;

b. Rector's policy to open a special path "Achievement of scientists, arts and sports" for students in rare study programs interested in

c. Empower Lecturers, Community Leaders and Alumni to socialize religious study programs for MA students; Vocational High School and Islamic Boarding School

d. The existence of MOU Job Vacancies between UIN and the Regional Government towards alumni in rare study programs interested in

e. Giving scholarships to students in quiet study programs

3. AFI Study Program must be more creative and innovative in disseminating its programs to MA, SMA, SMK and Islamic Boarding School students by involving alumni, lecturers and the community anyway.

4. The demands of the Main Performance Indicators (IKU), the Aqeedah Study Program and Islamic Philosophy of UIN Ar Raniry Banda Aceh must find various alternatives to increase the number of students each year. 
Acknowledgment. The author would like to thank the Head of the Center for Religious and Religious Education Research and Development Agency of the Ministry of Religion and Education for providing the opportunity for the author to conduct research on rare study programs of interest in PTKI. We would also like to thank the Head of Academic Section of UIN Ar Raniry Banda Aceh, the Chairperson of the Aqidah Study Program and Islamic Philosophy of U Ran Ar Banda Aceh, and all those who helped provide data and information in this study. Hopefully this article is useful for the development of post-graduate management in PTKI going forward.

\section{References}

[1] Statistik Pendidikan Islam tahun 2014/2015. Direktorat Pendidikan Tinggi Islam Kementerian Agama RI

[2] Puslitbang Penda. 2013. Eksekutif Summary Penelitian Pemetaan Kapasitas 6 UIN. Jakarta: Balitbang Kemenag.

[3] Puslitbang Penda. 2013. Laporan Penelitian Kapasitas 6 UIN. Jakarta;Balitbang Kementerian Agama.

[4] Nur Syam, Menyeimbangkan Prodi Agama dan umum, http://nursyam.uinsby.ac.id/?p=832.

[5] PMA nomor 37 tahun 2017, Perubahan atas peraturan menteri agama Nomor 33 tahun 2016 tentang gelar akademik Perguruan Tinggi Keagamaan.

[6] KONSEP MANAJEMEN PENDIDIKAN $\sim$ Kumpulan Makalah \& Artikel https:/makalah-ibnu.blogspot.com/2010/01/konsep-manajemen pendidikan.html \#ixzz5UDaEnf5h, diakses pada tanggal 17 Oktober 2018.

[7] Didin Kurniadin \& Imam machali. 2012. Manajemen Pendidikan Konsep dan Prinsip Pengelolaan Pendidikan. Jogjakarta: AR-RUZZ MEDIA.

[8] Oemar Hamalik. 2008. Manajemen Pengembangan Kurikulum. Bandung: Remaja Rosdakarya.

[9] https://dinarpratama.wordpress.com/2010/11/20/model-evaluasi-cipp-context-inputprocess-product/. Diakses pada Tanggal 18 Oktober 2018.

[10] Buku Pedoman Akademik. 2018. UIN Ar Raniry Aceh.

[11] Happy Saputra (2018) Wawancara, 13 September 2018. 